\title{
GREENHOUSE EVALUATION OF BACILLUS SUBTILIS AP-01 AND TRICHODERMA HARZIANUM AP-001 IN CONTROLLING TOBACCO DISEASES
}

\author{
Monchan Maketon $^{1}$; Jirasak Apisitsantikul²; Chatchai Siriraweekul ${ }^{2}$ \\ ${ }^{1}$ Zoology Department, Faculty of Science, Kasetsart University, Bangkok 10900, Thailand; ${ }^{2}$ Mae Jo Tobacco Experiment \\ Station, Amphor Sansai, Chiang Mai 50290 Thailand.
}

Submitted: May 16, 2007; Returned to authors for corrections: July 22, 2007; Approved: January 19, 2008.

\begin{abstract}
Two biological control agents, Bacillus subtilis AP-01 (Larminar ${ }^{\mathrm{TM}}$ ) and Trichoderma harzianum AP-001 $\left(\right.$ Trisan $^{\mathrm{TM}}$ ) alone or/in combination were investigated in controlling three tobacco diseases, including bacterial wilt (Ralstonia solanacearum), damping-off (Pythium aphanidermatum), and frogeye leaf spot (Cercospora nicotiana). Tests were performed in greenhouse by soil sterilization prior to inoculation of the pathogens. Bacterial-wilt and damping off pathogens were drenched first and followed with the biological control agents and for comparison purposes, two chemical fungicides. But for frogeye leaf spot, which is an airborne fungus, a spraying procedure for every treatment including a chemical fungicide was applied instead of drenching. Results showed that neither B. subtilis AP-01 nor T. harzianum AP-001 alone could control the bacterial wilt, but when combined, their controlling capabilities were as effective as a chemical treatment. These results were also similar for damping-off disease when used in combination. In addition, the combined B. subtilis AP01 and $T$. harzianum AP-001 resulted in a good frogeye leaf spot control, which was not significantly different from the chemical treatment.
\end{abstract}

Key-words: Biological control, tobacco diseases, bacterial wilt, damping off, frogeye leaf spot.

\section{INTRODUCTION}

Fine quality tobacco (Nicotiana tabacum L.) production in Thailand has been established a few decades ago. But a major hindrance in growing tobacco arose when tobacco diseases and insects attacked almost every planting season. Recently, the severity of tobacco diseases and insects increased not only in their number, but also in their resistance to chemical pesticides being used by farmers for plant protection. The higher the applied pesticide dosage resulted in the longer chemical residue in the tobacco leave. Therefore, in order to avoid this problem, Thailand Tobacco Monopoly, a state-own enterprise, has initiated a policy for producing organic tobacco. To find out whether natural biological control agents could be amenable for farmers, greenhouse testing was performed on tobacco diseases. Due to a large number of bacteria and fungi causing the-disease problems in Thailand, along with nematodes and virus from sucking insects, three of the most serious diseases were selected. These included bacterial wilt (Ralstonia solanacearum), damping-off (Pythium aphanidermatum), and frogeye leaf spot (Cercospora nicotiana). For the past decade, most research relied heavily on genetically modified tobacco to overcome the diseases problems $(8,9,15)$ In terms of using biological control agents, Fajola and Alasoadura $(5,6)$ have reported the use of Trichoderma harzianum Rafai in controlling damping-off from P. aphanidermatum. In the case of Bacillus subtilis, there are articles reported in controlling plant diseases but not exactly relevant to tobacco diseases $(1,2,11,12)$. Neither $R$. solanacearum nor C. nicotiana has been reported to be controlled by a biological control agent (BCA). Our research tested all three diseases with commercially available biological control products, a bacterium Bacillus subtilis AP-01 $\left(\right.$ Larminar $\left.^{\mathrm{TM}}\right)$ and a fungus Trichoderma harzianum Rifai strain AP-001 $\left(\right.$ Trisan $\left.^{\mathrm{TM}}\right)$, either alone or in combination. The data

*Corresponding Author. Mailing address: Zoology Department, Faculty of Science, Kasetsart University, Bangkok 10900, Thailand. Tel.: (662) 5625555 ext. 3202. E-mail: fscimcm@ku.ac.th 
was then compared with conventional chemical fungicides. So far, there is no record of combining B. subtilis and T. harzianum in controlling tobacco diseases, therefore, this innovative research explores a synergistic effect from both microorganisms.

\section{MATERIALS AND METHODS}

\section{Testing materials}

Tobacco variety burley K 326 was used. The following chemicals and biological control agents were used: propamocarb hydrochloride $72.2 \% \mathrm{SL}$ (Previcur-N ${ }^{\mathrm{TM}}$, AgrEvo GmbH, Germany), chlorothalonil 75\%WP (Daconil ${ }^{\mathrm{TM}}$, ISK Biosciences Corp., Japan), dazomet 5\%G (Basamid ${ }^{\mathrm{TM}}$, BASF AG, Germany), kasugamycin 2\% EC ( $\mathrm{Kasu}^{\mathrm{TM}}$, Arista Agro Corp., Japan), Bacillus subtilis strain AP-01 $1 \times 10^{9} \mathrm{cfu} / \mathrm{g}$ WP (Larminar $^{\mathrm{TM}}$, Appliedchem (Thailand) Co. Ltd.) and Trichoderma harzianum Rifai strain AP-001 2x10 $\mathrm{cfu} / \mathrm{g}$ WP (Trisan ${ }^{\mathrm{TM}}$, Appliedchem (Thailand) Co., Ltd.). Both pure cultures of B. subtilis AP-01 and T. harzianum AP-001 were deposited in the Culture Collection Center at Thailand Institute of Scientific and Technological Research (TISTR).

\section{Bacterial wilt (Ralstonia solanacearum)}

Refer to Table 1 for testing material and dosage for bacterial wilt. A pure culture of $R$. solanacearum was obtained from the collection of Mae Jo Tobacco Experiment Station. Disinfection of the soil in every testing pot by Dazomet $5 \% \mathrm{G}$ lasted 2 weeks, each pot filled with 3 kilogram soil. $R$. solanacearum suspension was inoculated $\left(1 \times 10^{5} \mathrm{cfu} / \mathrm{ml}\right)$ in every pot filled with disinfected soil at $300 \mathrm{ml}$ per pot. After 3 consecutive days, the testing materials were drenched according to each treatment as shown in Table 1 and then 45 days-old seedling were transplanted, one for each pot. Six treatments with four replications were performed and each replication consisted of five pots. The experiment was performed by a Completely Randomized Design (CRD). A compound fertilizer consisted of nitrogen, phosphate, and potassium (6-18-24) plus $4 \mathrm{MgO}$ and $0.5 \mathrm{~B}$ (Kemira Agro OY, Finland) was applied twice into each pot at 7 and 30 days after transplanting. The amount used was 25 grams for each application.

\section{Damping-off from Pythium aphanidermatum}

The methods were the same used for bacterial wilt. A pure culture of $P$. aphanidermatum was also obtained from Mae Jo Tobacco Experiment Station, and the concentration was $1 \times 10^{5}$ zoospores $/ \mathrm{ml}$. Treatment details are shown in Table 1.

\section{Frogeye leaf spot from Cercospora nicotiana}

A pure culture of $C$. nicotiana was also obtained from Mae Jo Tobacco Experiment Station. All methods were identical to the damping-off method with the exception of spraying $C$. nicotiana inoculum on tobacco seedling. The concentration

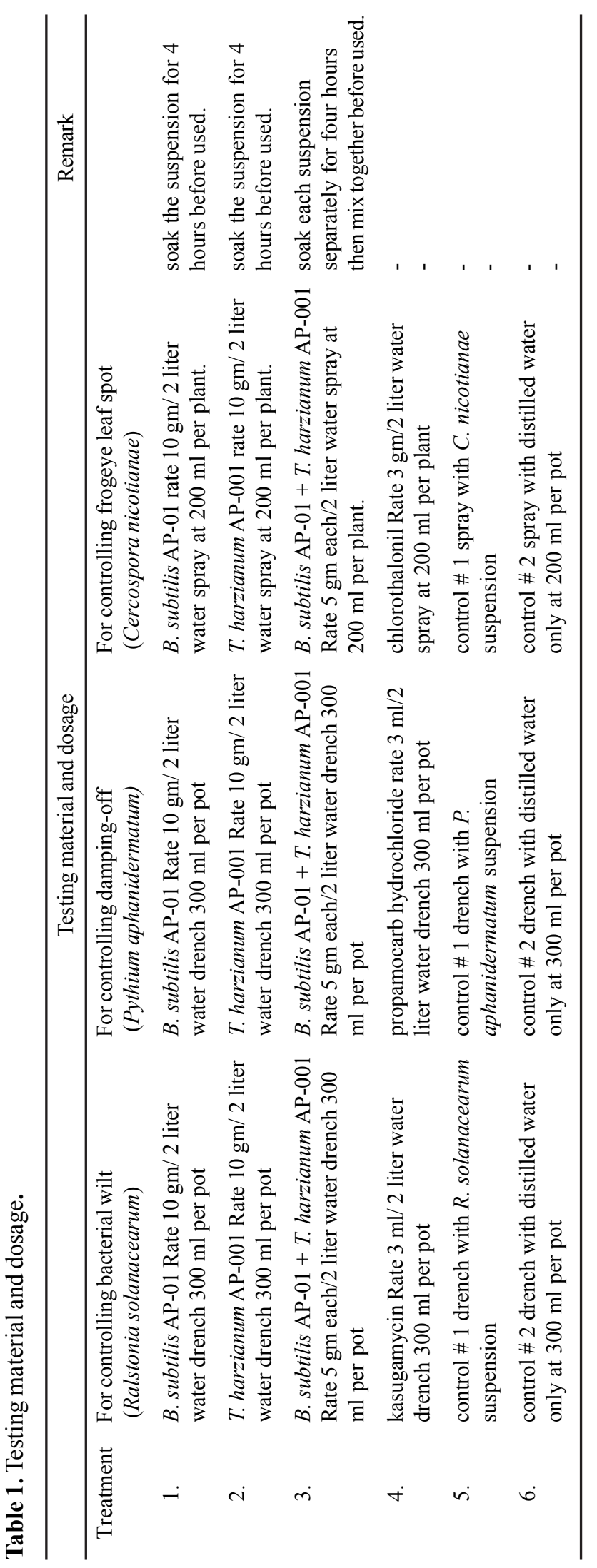


of C. nicotiana was $1 \times 10^{7}$ conidia $/ \mathrm{ml}$. Spraying of the testing materials started (Table 1.) 15 days after transplantation and followed with $C$. nicotiana suspension after two consecutive days.

In order to facilitate the disease infection, each plant was protected with a plastic bag for 15 days to retain moisture and spraying of the test materials was repeated four times at seven day intervals.

\section{Data analysis}

Data from bacterial wilt and damping-off were analyzed separately by analysis of variance (ANOVA). Results from frogeye leaf spot were submitted to Duncan's Multiple Range Test (DMRT) at $p=0.05$.

\section{RESULTS}

\section{Controlling bacterial wilt from Ralstonia solanacearum}

Wilt symptoms of tobacco plants have been observed and the numbers of wilted tobacco have been recorded at 20,30, and 40 days after transplantation. After 20 days, no significant difference was observed among the treatments $(p<0.05)$. However, the highest number of wilted tobacco appeared in an inoculated control treatment, followed with Trichoderma harzianum treatment and then Bacillus subtilis treatment. These results could have occurred from the antagonistic effects of $T$. harzianum and B. subtilis, but the capability of a fungus might not be as effective as a beneficial bacterium on a pathogenic one. Surprisingly, treatment with a mixture of both biological control agents (MBCA) presented efficacy to treatment equal with conventional chemical fungicide as shown in Fig. 1a. After 30 days, statistically, there was no significant difference of the wilted tobacco among all treatments, except the inoculated control treatment. However, the tendency of wilted tobacco in $T$. harzianum treatment still increased followed with the $B$. subtilis, MBCA, and chemical treatments, respectively. After 40 days, the hypotheses of whether biocontrol agents could be used to substitute chemical fungicide in controlling bacterial wilt have been verified. There was no significant difference among the treatments with MBCA, chemical, and the uninoculated control. No significant difference was noted with individual treatments of T. harzianum and inoculated control was but there a significant difference between the treatment with $T$. harzianum and the $B$. subtilis. This result indicates that either T. harzianum AP-001 or B. subtilis AP-01 alone had lower efficacies in controlling $R$. solanacearum than when combined, where some synergistic effect occurred.

\section{Controlling damping-off from Pythium aphanidermatum}

Damping-off symptom was observed and recorded at 30 and 45 days after transplanted onto the tobacco. After 30 days, treatment with $T$. harzianum alone or in combination with $B$. subtilis showed better results than $B$. subtilis alone or chemical treatment ( $p>0.05)$. As shown in Fig. 1b. After 45 days, B. subtilis AP-01 alone could not control P. aphanidermatum probably due to the weak colonization and parasitism of this isolate against the pathogen. The synergistic effect between $B$. subtilis AP-01 and T. harzianum AP-001 was observed. Their efficacy in controlling $P$. aphanidermatum did not differ from that of chemical fungicide $(p<0.05)$, but both treatments and uninoculated control were significantly different from the inoculated control.

\section{Controlling frogeye leaf spot from Cercospora nicotianae}

Disease severities were scored only once at 45 days after transplanting and recorded according to the following ranking: $1=$ no spot symptom in the leaf; 2 = symptoms occurred in $1 \%$ to $25 \%$ of the leaf area; $3=$ symptoms occurred in $26 \%$ to $50 \%$ of the leaf area; $4=$ symptoms occurred in $51 \%$ to $75 \%$ of the leaf area; and $5=$ symptoms occurred in $76 \%$ to $100 \%$ of the leaf area. Fig. 1c shows the results for BCA treatment, indicating that it presented the same good efficacy as the chemical treatment except $B$. subtilis AP-01 alone. This was a new phenomenon because the traditional practice for application of T. harzianum is soil drenching and/or seed dressing, since it is a soilborne fungus with saprophytic behavior, it will need both carbon and nitrogen from natural organic substances as food sources for its magnification in the plant's rhizosphere. However, as a common practice, the commercial product of T. harzianum AP-001 might have contained some nutrients for the fungus. Therefore, it could survived and performed its activities on the surfaces of leave, shank, stem and other parts of the plant. Therefore, in controlling bacterial wilt, damping-off, and frogeye leaf spot diseases in tobacco, a combination of $B$. subtilis AP01 and T. harzianum AP-001 showed as good efficacies as those recommended chemical fungicides.

\section{DISCUSSION}

As reported by Pierson and Weller (13), Duffy and Weller (3), Duffy et al. (4), Larkin and Fravel (10) and Howell (7), the use of combinations of multiple antagonistic organisms may provide improved disease control over the use of single organism. Multiple organisms may enhance the level and consistency of control by providing multiple mechanisms of action, more stable rhizosphere community, and be effective over a wider range of environmental conditions. In particular, combinations of fungi and bacteria may provide protection at different times or under various conditions, and occupy different or complementary niches. Such combinations may overcome inconsistencies in the performance of individual isolates.

In term of using biological control agents for foliar application, Raj et al. (14) reported that foliar spray was found to be a more efficient delivery method than seed treatment or 

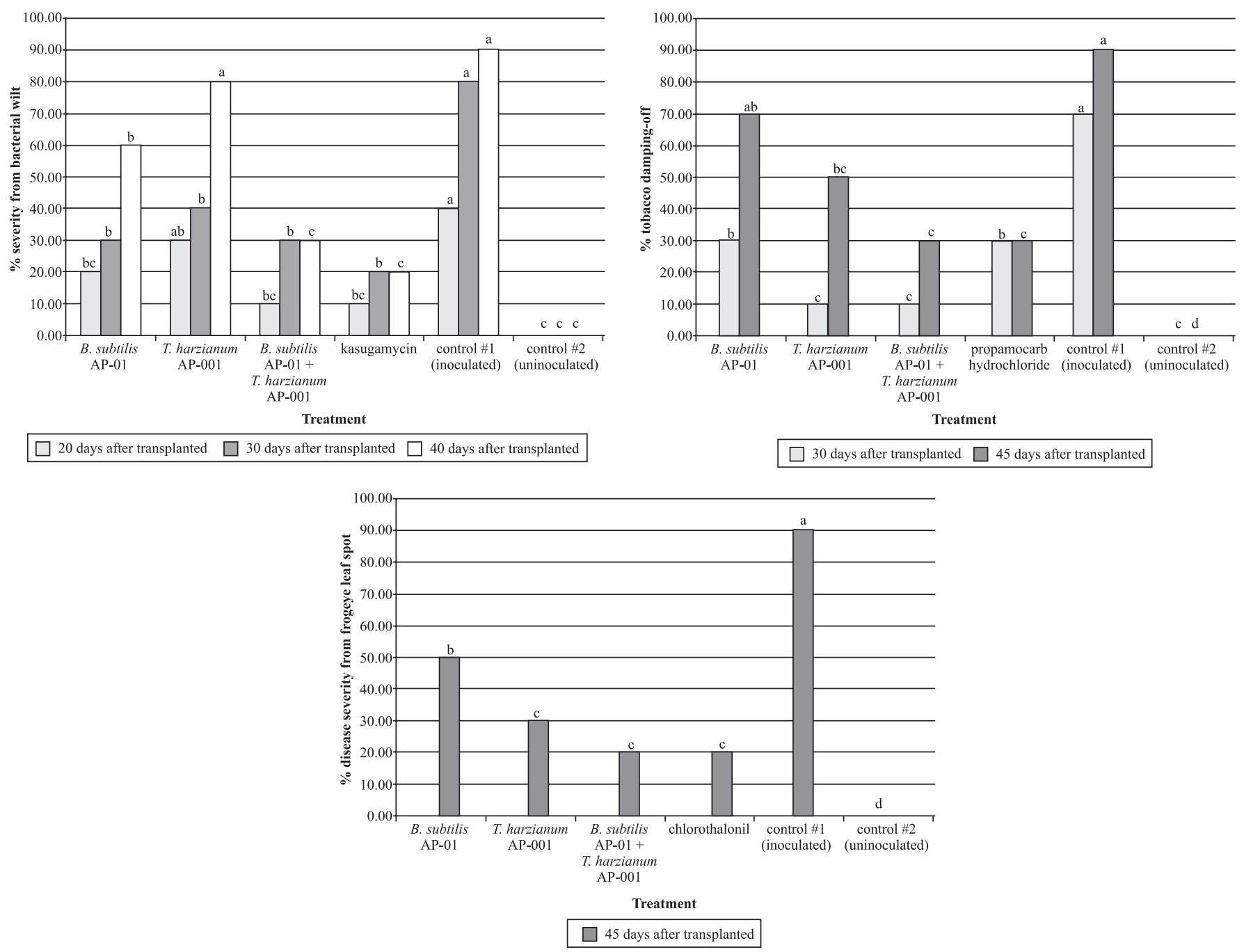

Figure 1. Percentage of tobacco disease severity from a) bacterial wilt (Ralstonia solanacearum), b) damping-off (Pythium aphanidermatum) and c) frogeye leaf spot (Cercospora nicotianae).

Means followed by the same letter in the same observation day showed no significant difference at $p=0.05$ by Duncan's Multiple Range Test.

slurry treatment. In addition, combinations of foliar spray with seed treatment and slurry treatment produced the same effect as foliar spray alone in controlling downy mildew, which is an airborne disease. Besides colonization and parasitism, some antibiosis metabolites may be secreted from this fungal isolate. On the contrary, some isolates of $B$. subtilis have been developed in the private sector into a sprayable formulation for controlling some airborne diseases, however, this isolate alone was not so effective in controlling C. nicotianae. Nevertheless, when combined, the efficacy was better than the chemical treatment. Brewer and Larkin (2) also found that some of the biological control treatments reduced disease as well as the chemical control, suggesting synergistic effects. However, there was no significant difference among the treatments with $T$. harzianum, MCBA, and chemical but they were significantly different from B. subtilis inoculated and uninoculated controls.

Future research should concentrate into the metabolites the microbes produced and what happens when they are applied in combination, since individual application of these microbes could not control the plant disease. Although, greenhouse conditions differ from field plantations, our research showed feasibility in employing biological control agents for plant diseases, further eliminating the need for chemical pesticides.

The main ideology of organic farming is to refrain from using chemical fertilizers and pesticides, but in this study a combination of nitrogen, phosphate, and potash fertilizer was 
used because tobacco is not a common leafy vegetable crop. Tobacco will need an exact macronutrient formulation for not only its growth but for other performances such as flavor, aroma, burn character, etc. Therefore, organic fertilizer either compost or animal dung could not achieve those special characteristics. In addition, organic fertilizers which contain mainly nitrogen will stimulate vegetative growth so quickly that it may affect tobacco physiology, favoring plant disease.

\section{ACKNOWLEDGEMENTS}

We would like to thank Ms. Chutimun Panichsakpatana, Thai Department of Agriculture for her comments and Ms. Patricia Orosz-Coghlan, Soil, Water \& Environmental Science Department, The University of Arizona, for manuscript correction.

\section{RESUMO}

\section{Avaliação em estufa de dois agentes biológicos de controle de doenças do tabaco}

Dois agentes de controle biológico, Bacillus subtilis AP-01 (Larminar®) e Trichoderma harzianum AP-001 (Trisan ${ }^{\circledR}$ ) foram avaliados separadamente ou em combinação quanto à capacidade de controlar três doenças do tabaco: murcha bacteriana (bacterial wilt, Ralstonia solanacearum), tombamento de mudas (damping-off, Pythium aphanidermatum), e mancha olho-de-rã (frogeye leaf spot, Cercospora nicotiana). Os testes foram realizados em estufa, esterilizando-se o solo antes da inoculação dos patógenos. Os patógenos causadores da murcha bacteriana e tombamento de mudas foram inicialmente encharcados e acompanhados com os agentes de controle biológico e, para comparação, com um fungicida químico. Para a mancha olho-de-rã, causada por um fungo anemófilo, utilizouse um processo de spray ao invés do encharcamento. Os resultados indicaram que nenhum dos dois agentes de controle biológico, aplicado isoladamente, foi capaz de controlar a murcha bacteriana, mas quando em combinação a capacidade de controle foi similar ao do tratamento químico. Resultados semelhantes foram obtidos para o tombamento de mudas. Além disso, a combinação de Bacillus subtilis AP-01 e Trichoderma harzianum AP-001 resultou em um controle muito eficiente da mancha olhode-rã, que não diferiu significativamente daquele obtido com o tratamento químico.

Palavras-chave: controle biológico, doenças do tabaco, murcha bacteriana, tombamento de mudas, mancha olho-de-rã

\section{REFERENCES}

1. Asaka, O.; Shoda, M. (1996). Biocontrol of Rhizoctonia solani damping off of tomato with Bacillus subtilis RB14. Appl. Environ. Microbiol., 62 (11), 4081-4085.

2. Brewer, M.T.; Larkin, R.P. (2005). Efficacy of several potential biocontrol organisms against Rhizoctonia solani on potato. Crop Protection., 24 (11), 939-950.

3. Duffy, B.K.; Weller, D.M. (1995). Use of Gaemannomyces graminis var. graminis alone and in combination with fluorescent Pseudomonas spp. to suppress take-all of wheat. Plant Dis., 79, 907-911.

4. Duffy, B.K.; Simon, A.; Weller, D.M. (1996). Combination of Trichoderma koningii with fluorescent pseudomonads for control of take-all on wheat. Phytopathology, 86,188-194.

5. Fajola, A-O.; Alasoadura, S.O. (1974). Studies on the damping-off disease of tobacco (Nicotiana tabacum L.) in Nigeria. Mycopathologia, 52 (3-4), 239-249.

6. Fajola, A-O.; Alasoadura, S.O. (1975). Antagonistic effects of Trichoderma harzianum on Pythium aphanidermatum causing the damping-off disease of tobacco in Nigeria. Mycopathologia, 57 (1), 47-52.

7. Howell, C.R. (2003). Mechanisms employed by Trichoderma species in the biological control of plant diseases: the history and evolution of current concepts. Plant Dis., 87, 4-10.

8. Huang, Y.; McBeath, J.H. (1994). Bacterial induced activation of an Arabidopsis phenylalanine ammonia-lyase promoter in transgenic tobacco plants. Plant Sci., 98 (1), 25-35.

9. Jaynes, J.M.; Nagpala, P.; Beltran, L.D.; Huang, J.H.; Kim, J.; Denny, T.; Cetiner, S. (1993). Expression of a Cecropin B lytic peptide analog in transgenic tobacco confers enhanced resistance to bacterial wilt caused by Pseudomonas solanacearum. Plant Sci., 89 (1), 4353

10. Larkin, R.P.; Fravel, D.R. (1998). Efficacy of various fungal and bacterial biocontrol organisms for control of Fusarium wilt of tomato. Plant Dis., 82, 1022-1028.

11. Maketon, M. (2004). Effectiveness of "Biobest" (Bacillus subtilis NSRS89-24+ MK-007) in Controlling Rice Sheath Blight Disease from Rhizoctonia solani Kuhn. KU. Sci. J., 22 (1), 24-30.

12. Nemec, S.; Datnoff, L.E.; Strandberg, J. (2003). Efficacy of biocontrol agents in planting mixes to colonize plant roots and control root diseases of vegetables and citrus. Crop Prot., 15 (8), 735-742.

13. Pierson, E.A.; Weller, D.M. (1994). Use of mixtures of fluorescent pseudomonads to suppress take-all and improve the growth of wheat. Phytopathology, 84, 940-947.

14. Raj, S.N.; Shetty, N.P.; Shetty, H.S. (2005). Synergistic effects of Trichoshield on enhancement of growth and resistance to downy mildew in pearl millet. Biocontrol., 50, 493-509.

15. Ragueh, F.; Lescure, N.; Roby, D.; Marco, Y. (1989). Gene expression in Nicotiana tabacum in response to compatible and incompatible isolates of Pseudomonas solanacearum. Physiol. Mol. Plant Pathol., 35 (1), 23-33. 